\title{
EFFECT OF DIFFERENT GIBBERELLIC ACID DOSES AND APPLICATION TIMES ON COTTON (Gossypium hirsutum L.) IN SOUTHEASTERN ANATOLIA REGION OF TURKEY
}

\author{
COPUR, O. ${ }^{1 *}-$ DEMIREL, T. $^{2}-$ OdABAȘIOĞLU, C. ${ }^{1}$ \\ ${ }^{1}$ Department of Field Crops, Faculty of Agriculture, Harran University, 63190 Sanliurfa, \\ Turkey \\ ${ }^{2}$ Department of Field Crops, Graduate School of Natural and Applied Sciences, Harran \\ University, 63190 Sanliurfa, Turkey \\ *Corresponding author \\ e-mail: ocopur@harran.edu.tr; phone: +90-414-318-3690
}

(Received 24 $4^{\text {th }}$ Jun 2019; accepted $16^{\text {th }}$ Oct 2019)

\begin{abstract}
This study was carried out to determine the impact of different gibberellic acid $\left(\mathrm{GA}_{3}\right)$ application times and doses on seed cotton yield and yield components of Stoneville 468 cotton variety in Southeastern Anatolia Region. Experiments were conducted using randomized block design with split plots and with three replications during the 2015 and 2016 growing seasons. Where application times formed the main plots (control, beginning of squaring, beginning of squaring + beginning of flowering and beginning of squaring + beginning of flowering +14 days after the beginning of flowering one application), application doses formed the sub plots (control, 400, 800, $1200 \mathrm{cc} \mathrm{ha}^{-1}$ ). Resulting, seed cotton yields varied between $4882.77 \mathrm{~kg} \mathrm{ha}^{-1}$ and $5557.15 \mathrm{~kg} \mathrm{ha}^{-1}$. While the doses of gibberellic acid increased; seed cotton yield, number of bolls per plant, number of sympodia per plant, plant height, seed cotton weight per boll, ginning outturn, seed index, fiber length and fiber uniformity increased, but earliness ratio and fiber fineness decreased. The most suitable GA dose was $1200 \mathrm{cc} \mathrm{ha}^{-1}$ and the highest seed cotton yield was obtained from the beginning of squaring + beginning of flowering +14 days after beginning of flowering administered three times.
\end{abstract}

Keywords: plant growth regulator, sympodia, fiber quality, yield, yield components

\section{Introduction and literature review}

Cotton fibers have great economic importance for cotton producing countries with their widely usage areas, added value and created employment opportunities in the textile sector. With the increasing population, increasing interest for natural fibers and living standards increase the demand of cotton fibers. However, because a limited number of countries' ecology allows the cotton farming, about $80 \%$ of world production is carried by eight countries including Turkey (Anonymous, 2019a). Cotton farming area in Turkey was 518000 ha in 2018 and 976000 tons of cotton fiber were produced from this area. Cotton is grown in Aegean, Mediterranean (Cukurova and Antalya province) and Southeastern Anatolia Regions of Turkey, although 56\% of the cotton is produced in Southeastern Anatolia Region, especially 40\% of them in the province of Sanliurfa (Anonymous, 2019b). Therefore, Sanliurfa has an important place in the cotton production of Turkey. This ratio is expected to increase with the completion of SAP (Southeastern Anatolian Project) irrigation and energy projects.

Since the cotton is an important industrial product in both export and domestic consumption, many studies are carried out to increase the seed cotton yield and fiber quality characteristics. One of these studies is using and investigating various plant growth regulators in addition to conventional cotton growing techniques. Plant growth 
regulators are important in terms of researching the possibilities of improving yield and quality potential gained by breeding, growing techniques and ecology by affecting mostly the growth physiology of the plant. In recent years, usage of plant growth regulators has become widespread in the application of agricultural chemicals. Plant growth regulators; they are chemical substances that are synthesized by plants or synthetically synthesized and given to the plant from the outside, which can affect growth, development and other physiological events of plants even in very small proportions, and can be effective in the tissues they form as well as in other plant tissues and organs in which they are carried. These chemicals are called hormone when it is synthesized in the plant and called plant growth regulator when they are synthesized artificially outside of the plant (Kurt et al., 1994; Çopur et al., 2010 and Parveen et al., 2017).

It is possible to create suitable conditions for plant growth to achieve high yields for cotton. In addition to suitable environmental conditions, good agronomic practices (soil tillage, fertilization, pest and disease control, irrigation, plant growth regulators, etc.) have important effects in order to obtain the highest yields (Mert et al., 2015). Some adverse environmental conditions (excessive vegetative growth, etc.) that come up during the growing period can be mitigated by good agronomical practices. Squaring, flowering and boll formation periods are the most critical periods for cotton plant. In this period, some wrong practices in plant management are directly reflected in the yield and may cause yield losses. Climatic factors such as high temperature, day length and relative humidity may adversely affect the synthesis of certain hormones that form in the plants. Eventually, physiological events happening in the plant are directly affected by this situation and the plants cannot demonstrate its yield potential. Therefore, in order to minimize or completely eliminate the negative effects of environmental conditions on plants, the application of some phyto-hormones to plants with different formation and effect patterns is important for the continuation of physiological events in the normal course and to find out the maximum yield potential (Güllüoğlu, 2004). One of the plant growth regulators commonly used in agricultural production is gibberellic acid. Gibberellic acid is currently not used commercially as licensed for cotton production in Turkey, but it is observed that producers sometimes apply.

Gibberellic acid, called $\mathrm{GA}_{3}$, is a natural compound used for flowering and for better growth of bolls in plants. Plants produce about 90 pcs of gibberellins (Davies, 1995). Almost no evidence has been found the Gibberellins to harm human health up to now. Gibberellic acid is a plant growth regulator derived from a fungal species called Gibberella fujikuroi. Plant pathologists in Japan discovered this fungus in 1926. The fungus used for the first time in rice seedlings was found to cause very tall and thin growth of plants (Davies, 1995). Gibberellic acid is obtained by fermentation of Gibberella fungus in large barrels. It is sold in powder and liquid forms which are soluble in water. Gibberellic acid has vital importance for plants and increases the growth and development of the plant (Bora and Sarma, 2006). It can also be used to increase flowering, boll formation and size. Gibberellic acid forms naturally in plants and regulates plant growth. Low dose of $\mathrm{GA}_{3}$ promotes seed growth but does not have a permanent effect on the seed.

In studies of $\mathrm{GA}_{3}$ in plants; it is reported that different doses study on cotton plant was not affect the yield potential (McCarty et al., 2009); applications of $100 \mathrm{mg} \mathrm{L}^{-1}$ and at the 6-7 leaves period for onion plant increased seed yield per umbrella (Mustaq et al., 2018); and olive yield per tree increased by the applications (Ülger et al., 2018). 
The aim of this study is to determine the effect of different gibberellic acid dosages and application times on the yield and yield components of middle early Stoneville-468 cotton variety under Harran Plain with semi-arid climatic conditions and to provide a source for the studies to be carried out on this subject.

\section{Materials and methods}

The experiments were conducted in the Eyyubiye Campus experimental area of Agricultural Faculty of Harran University during 2015 and 2016 growing seasons (Fig. 1). The average altitude of the trial area is $465 \mathrm{~m}$ and it is located at $37^{0} 08^{\prime} \mathrm{N}$ latitude and $38^{\circ} 46^{\prime} \mathrm{E}$ longitude and close to the Syrian border. The trial area is clay $(62 \%)$, organic matter is low $(0.5-1.2 \%)$ and $\mathrm{pH}$ is 7.2 (Table 1). The trial area is classified as the Ikizce soil series (Vertic Calciorthid Aridisol) (Anonymous, 2006). Southeastern Anatolia region has semi-arid climatic conditions, summers are hot and dry, and winters are temperate and rainy. In summer the temperature can reach up to $44.1{ }^{\circ} \mathrm{C}$ (Table 2). Total rainfall in the region in 2015 and 2016 were 312.3 and $440.8 \mathrm{~mm}$ respectively. For this purpose, the study was carried out under irrigated conditions. The average temperature for long years was $18.3^{\circ} \mathrm{C}$, the average humidity was $50.3 \%$ and the average wind speed was $2.2 \mathrm{~m} \mathrm{~s}^{-1}$ (Anonymous, 2017).

The experiments were carried out in randomized block design with split plots and with 3 replications. Application times formed the main plots (beginning of squaring, beginning of squaring + beginning of flowering and beginning of squaring + beginning of flowering + application after 14 days of flowering) and application doses formed the sub plots (Table 3). Stoneville-468 cotton (Gossypium hirsutum L.) variety was used as plant material. Cotton seeds were sown with cotton trial driller in 4 rows and $10 \mathrm{~m}$ in length with $70 \mathrm{~cm}$ inter-row spaces on 01 May in 2015 and 03 May in 2016. After emergence, the plants were thinned with a distance of $15-20 \mathrm{~cm}(50-60$ plants in each row) at the time of 4-5 leaves period.

In the experiments, $70 \mathrm{~kg} \mathrm{ha}^{-1}$ pure nitrogen and $70 \mathrm{~kg} \mathrm{ha}^{-1}$ pure phosphorus was applied as a 20.20 .0 compound fertilizer. The remaining $90 \mathrm{~kg} \mathrm{ha}^{-1}$ pure nitrogen was applied as a urea fertilizer ( $46 \%$ pure nitrogen) with the lister machine before the first irrigation. A total of $1050 \mathrm{~mm}$ of water was applied during growing season. The first irrigation was applied 4 weeks after sowing, and the other irrigations were practiced 10 times in 10-day intervals. Last irrigation was applied when 10\% of the bolls in the plots opened.

Table 1. Some soil properties of the study area (Harran University Research Station, Sanliurfa, Turkey)

\begin{tabular}{|c|c|c|c|c|c|c|c|c|c|c|c|}
\hline \multirow{2}{*}{$\begin{array}{l}\text { Depth } \\
(\mathbf{c m})\end{array}$} & \multirow{2}{*}{$\begin{array}{c}\text { BD } \\
\left(\mathrm{g} \mathrm{cm}^{-3}\right)\end{array}$} & \multirow{2}{*}{$\begin{array}{l}\text { OM } \\
(\%)\end{array}$} & \multicolumn{3}{|c|}{$\begin{array}{c}\text { Soil particle distribution } \\
(\%)\end{array}$} & \multirow[t]{2}{*}{ pH } & \multirow{2}{*}{$\begin{array}{c}\mathbf{N} \\
\left(\mathrm{kg} \mathrm{ha}^{-1}\right)\end{array}$} & \multirow{2}{*}{$\begin{array}{c}\mathrm{P}_{2} \mathrm{O}_{5} \\
\left(\mathrm{~kg} \mathrm{ha}^{-1}\right)\end{array}$} & \multirow{2}{*}{$\begin{array}{c}\mathbf{K}_{2} \mathrm{O} \\
\left(\mathrm{kg} \mathrm{ha}^{-1}\right)\end{array}$} & \multirow{2}{*}{$\begin{array}{l}\text { FC } \\
(\%)\end{array}$} & \multirow{2}{*}{$\begin{array}{l}\text { PWP } \\
(\%)\end{array}$} \\
\hline & & & Sand & Silt & Clay & & & & & & \\
\hline $0-30$ & 1.37 & 1.2 & 7 & 34 & 59 & 7.3 & 25 & 27 & 1280 & 31.5 & 22.2 \\
\hline $30-60$ & 1.40 & 0.8 & 17 & 25 & 58 & 7.2 & 12 & 20 & 900 & 31.8 & 22.6 \\
\hline $60-90$ & 1.43 & 0.6 & 20 & 21 & 59 & 7.2 & 6 & 17 & 810 & 32.3 & 21.5 \\
\hline $90-120$ & 1.43 & 0.5 & 19 & 20 & 62 & 7.2 & - & - & - & 32.5 & 21.5 \\
\hline
\end{tabular}

BD: bulk density, OM: organic matter, FC: field capacity, PWP: permanent wilting point 


$$
\text { - } 14988 \text { - }
$$

Table 2. Climatic data of the experimental area during cotton crop growing season for the years 2015 and 2016

\begin{tabular}{|c|c|c|c|c|c|c|}
\hline Climatic parameters & May & June & July & August & September & October \\
\hline \multicolumn{7}{|c|}{2015} \\
\hline Min. air temp. $\left({ }^{\circ} \mathrm{C}\right)$ & 11.8 & 16.7 & 21.4 & 22.1 & 18.7 & 12.7 \\
\hline Max. air temp. $\left({ }^{\circ} \mathrm{C}\right)$ & 38.4 & 42.8 & 43.1 & 40.4 & 33.0 & 24.3 \\
\hline Average air temp. $\left({ }^{\circ} \mathrm{C}\right)$ & 30.1 & 27.7 & 33.2 & 33.5 & 29.8 & 21.6 \\
\hline Relative humidity (\%) & 38.0 & 40.1 & 37.9 & 37.4 & 42.7 & 50.5 \\
\hline Wind speed $\left(\mathrm{ms}^{-1}\right)$ & 1.6 & 1.9 & 1.6 & 1.3 & 1.4 & 1.5 \\
\hline Soil temperature $\left({ }^{\circ} \mathrm{C}\right)$ & 24.3 & 29.0 & 32.3 & 32.9 & 30.7 & 23.8 \\
\hline Rainfall (mm) & 10.3 & 20.6 & --- & 1.0 & 30.5 & 58.8 \\
\hline \multicolumn{7}{|c|}{2016} \\
\hline Min. air temp. $\left({ }^{\circ} \mathrm{C}\right)$ & 10.7 & 18.9 & 20.9 & 21.2 & 14.7 & 12.3 \\
\hline Max. air temp. $\left({ }^{\circ} \mathrm{C}\right)$ & 35.0 & 42.0 & 43.0 & 43.0 & 39.3 & 33.9 \\
\hline Average air temp. $\left({ }^{\circ} \mathrm{C}\right)$ & 23.2 & 29.8 & 33.0 & 33.2 & 26.4 & 22.1 \\
\hline Relative humidity (\%) & 38.3 & 28.0 & 25.4 & 30.6 & 32.1 & 35.9 \\
\hline Wind speed $\left(\mathrm{ms}^{-1}\right)$ & 1.9 & 1.9 & 1.7 & 1.6 & 1.7 & 1.2 \\
\hline Soil temperature $\left({ }^{\circ} \mathrm{C}\right)$ & 25.5 & 31.2 & 34.5 & 35.1 & 30.7 & 24.6 \\
\hline Rainfall (mm) & 12.3 & 0.6 & 0.2 & --- & --- & 17.6 \\
\hline \multicolumn{7}{|c|}{ Average temperatures for 46 years period $(1970-2016)$} \\
\hline Min. air temp. $\left({ }^{\circ} \mathrm{C}\right)$ & 6.0 & 10.0 & 16.00 & 16.0 & 11.2 & 2.5 \\
\hline Max. air temp. $\left({ }^{\circ} \mathrm{C}\right)$ & 40.0 & 44.0 & 46.8 & 44.8 & 42.0 & 36.4 \\
\hline Average air temp. $\left({ }^{\circ} \mathrm{C}\right)$ & 22.3 & 28.2 & 32.0 & 31.2 & 26.8 & 20.3 \\
\hline Relative humidity (\%) & 46.2 & 34.9 & 32.2 & 35.3 & 37.9 & 47.5 \\
\hline Wind speed $\left(\mathrm{ms}^{-1}\right)$ & 1.9 & 2.4 & 2.4 & 2.2 & 1.9 & 1.4 \\
\hline Soil temperature $\left({ }^{\circ} \mathrm{C}\right)$ & 25.8 & 33.2 & 37.4 & 36.3 & 31.0 & 22.6 \\
\hline Rainfall (mm) & 25.7 & 3.6 & 0.7 & 1.1 & 3.2 & 25.3 \\
\hline
\end{tabular}

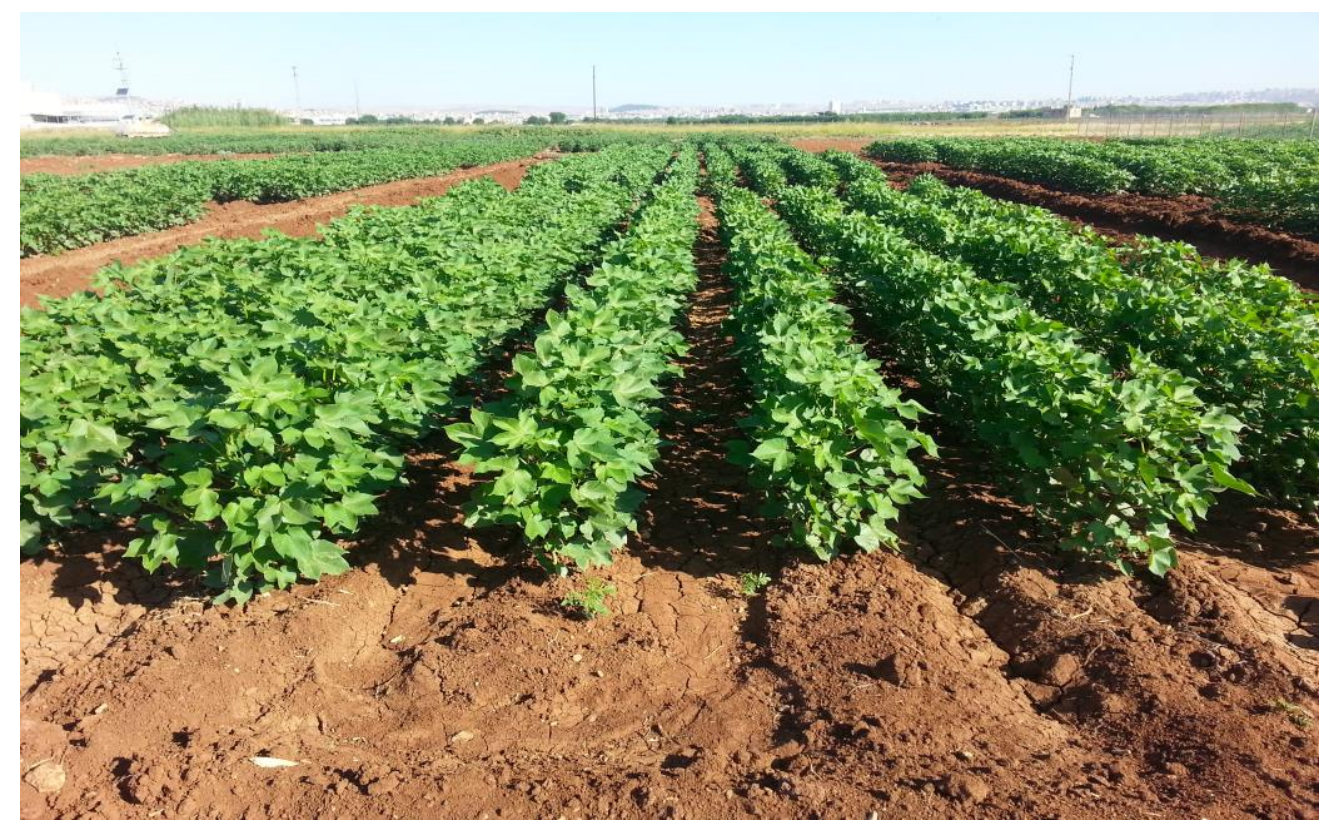

Figure 1. Photography from the experimental field 
Table 3. Gibberellic acid doses and application times

\begin{tabular}{c|c|c|c|c}
\hline Growing stages & \multicolumn{4}{|c}{ Application doses (cc ha-1) } \\
\hline 1. PHS (cc ha-1) & WA (T1) & $400(\mathrm{~T} 2)$ & $800(\mathrm{~T} 3)$ & $1200(\mathrm{~T} 4)$ \\
2. PHS + FF & WA & $200+200$ & $400+400$ & $600+600$ \\
3. PHS + FF + after two weeks & WA & $133+133+134$ & $266+267+267$ & $400+400+400$ \\
\hline
\end{tabular}

PHS: pin head square, FF: first flower, T: treatment, WA: water application

During the growing season in the experimental years, the plants were hoed two times by hand and three times by tractor. Before the application of $\mathrm{GA}_{3}$, the pressure regulated back pump was calibrated with water and the required amount of water was determined and then $\mathrm{GA}_{3}$ was mixed with water and applied to the plots when the air temperature was $28-30{ }^{\circ} \mathrm{C}$ before midday. Control plots were sprayed with water only.

Agronomic practices were applied in the experiment based on the studies conducted in the region. First-hand harvests were carried out by hand on 18 and 20 September, and second-hand harvests on 15 and 20 October in 2015 and 2016 respectively. According to Worley et al. (1976), seed cotton yield, plant height, number of sympodia branches, number of bolls, seed cotton weight per boll, ginning outturn and 100 seed weight were examined; fiber length, fiber fineness, fiber strength and fiber uniformity characteristics were examined by HVI Spectrum instrument (Anonymous, 1997). The data determined according to the methods were analyzed separately each year according to the split plots trial design by using the MSTAT-C package program and the means were compared according to LSD test (Anonymous, 1989).

\section{Results and discussion}

\section{Seed cotton yield ( $\left.\mathrm{kg} \mathrm{ha}^{-1}\right)$}

Table 4 shows that the average seed cotton yield in terms of $\mathrm{GA}_{3}$ application doses ranged from $4800 \mathrm{~kg} \mathrm{ha}^{-1}$ to $5500 \mathrm{~kg} \mathrm{ha}^{-1}$ in 2015 and 2016 years. It was determined that the seed cotton yield increased with increasing of $\mathrm{GA}_{3}$ doses and the highest and lowest seed cotton yield were obtained from $1200 \mathrm{cc} \mathrm{ha}^{-1}$ and control plot respectively. In terms of application times, the highest seed cotton yield was obtained from PHS + FF + application after two weeks. According to LSD (Least Significant Difference) test, it was determined that different yield groups were formed in terms of application doses and times in both years, while application times $\times$ dose interactions were found insignificant in 2015 but were found significant in 2016 (Table 4). Seed cotton yield is a complex character affected by genotypic and environmental conditions (Worley et al., 1974). In addition to genotype and environmental conditions, chemicals that are applied artificially by external cultivation techniques can also affect dry matter production per unit area (Kurt et al., 1994). From Table 4, it can be observed that the seed cotton yield was positively affected by increasing doses of gibberellic acid and increased seed cotton yield. Gibberellic acid applications contributed to increase the number of squares, but also increased boll fall, hence had no effect on the seed cotton yield is indicated by Emiroglu and Turan (1974) and McCarty et al. (2009). Eid et al. (1986) in the study of the GA 3 applications during squaring and flowering period increased the seed cotton yield. $\mathrm{GA}_{3}$ positively affects the formation of new cells by accelerating cell division and elongation in meristematic tissues and as a result, it has been reported that $\mathrm{GA}_{3}$ have a positive effect 
on plant growth and flax seed yield (Emongor, 2007 and Rastogi et al., 2013). Our results are compatible with the findings of Eid et al. (1986) but were partially contradictory with the findings of Emiroglu and Turan (1974) and McCarty et al. (2009). As indicated above, different results were published by several researchers. This may be due to cotton genotypes used in the study and changing GA doses and application times. As different locations have different climatic and soil characteristics, variable results can occur.

Table 4. Seed cotton yield, earliness ratio and plant height and its contributions in response to gibberellic acid and growing stages in 2015 and 2016

\begin{tabular}{|c|c|c|c|c|c|c|}
\hline \multirow{2}{*}{ GA application doses } & \multicolumn{2}{|c|}{$\begin{array}{c}\text { Seed cotton yield } \\
\left(\mathrm{kg} \mathrm{ha}^{-1}\right)\end{array}$} & \multicolumn{2}{|c|}{$\begin{array}{c}\text { Earliness ratio } \\
(\%)\end{array}$} & \multicolumn{2}{|c|}{$\begin{array}{c}\text { Plant height } \\
(\mathrm{cm})\end{array}$} \\
\hline & 2015 & 2016 & 2015 & 2016 & 2015 & 2016 \\
\hline Control (C) & $4882.77 \mathrm{c}$ & $4891.71 \mathrm{c}$ & $94.23 \mathrm{a}$ & $94.63 \mathrm{a}$ & $89.63 \mathrm{c}$ & 102.73 \\
\hline $\mathrm{GA}_{1}\left(400 \mathrm{cc} \mathrm{ha}^{-1}\right)$ & $5146.02 \mathrm{~b}$ & $5089.33 \mathrm{bc}$ & $92.62 \mathrm{ab}$ & $89.21 b$ & $96.13 \mathrm{bc}$ & 106.09 \\
\hline $\mathrm{GA}_{2}\left(800 \mathrm{cc} \mathrm{ha}^{-1}\right)$ & $5400.56 \mathrm{ab}$ & $5242.61 \mathrm{ab}$ & $90.45 \mathrm{bc}$ & $89.88 \mathrm{~b}$ & $102.95 \mathrm{ab}$ & 108.02 \\
\hline $\mathrm{GA}_{3}\left(1200 \mathrm{cc} \mathrm{ha}{ }^{-1}\right)$ & $5557.15 \mathrm{a}$ & $5353.69 \mathrm{a}$ & $87.87 \mathrm{c}$ & $85.48 \mathrm{c}$ & $107.85 \mathrm{a}$ & 111.14 \\
\hline \multicolumn{7}{|l|}{ Growing stage (GS) } \\
\hline $\mathrm{PHS}^{1}$ & $5054.64 \mathrm{~b}$ & $4937.98 \mathrm{~b}$ & 90.32 & 90.65 & 99.63 & $105.03 \mathrm{~b}$ \\
\hline $\mathrm{PHS}+\mathrm{FF}^{2}$ & $5228.85 \mathrm{ab}$ & $5095.52 \mathrm{~b}$ & 91.14 & 89.89 & 98.90 & $106.40 \mathrm{~b}$ \\
\hline $\mathrm{PHS}+\mathrm{FF}+$ after two weeks & $5456.39 \mathrm{a}$ & $5399.52 \mathrm{a}$ & 90.73 & 88.87 & 98.89 & $109.57 \mathrm{a}$ \\
\hline \multicolumn{7}{|l|}{ Interaction } \\
\hline $\mathrm{CxGS}_{1}$ & 4877.21 & $4747.33 \mathrm{c}$ & 94.23 & 94.65 & 89.63 & 102.73 \\
\hline $\mathrm{CxGS}_{2}$ & 4800.24 & $4863.97 \mathrm{c}$ & 93.34 & 90.79 & 100.03 & 104.37 \\
\hline $\mathrm{CxGS}_{3}$ & 5204.04 & $5067.12 \mathrm{bc}$ & 89.06 & 90.74 & 104.43 & 105.33 \\
\hline $\mathrm{G}_{1} \times \mathrm{GS}_{1}$ & 5337.06 & $5083.48 \mathrm{bc}$ & 84.67 & 86.41 & 104.43 & 107.67 \\
\hline $\mathrm{G}_{1} \times \mathrm{GS}$ & 4877.21 & $4870.70 \mathrm{c}$ & 94.23 & 94.63 & 89.63 & 102.73 \\
\hline $\mathrm{G}_{1} \times \mathrm{GS}_{3}$ & 5277.17 & 5057.12 bc & 91.53 & 87.78 & 93.56 & 105.27 \\
\hline $\mathrm{G}_{2} \times \mathrm{GS}_{1}$ & 5250.47 & $5120.35 \mathrm{bc}$ & 90.60 & 90.07 & 103.33 & 107.13 \\
\hline $\mathrm{G}_{2} \times \mathrm{GS}_{2}$ & 5510.55 & $5333.90 \mathrm{ab}$ & 88.20 & 87.07 & 109.10 & 110.47 \\
\hline $\mathrm{G}_{2} \mathrm{xGS} \mathrm{S}_{3}$ & 4893.88 & $5067.12 \mathrm{bc}$ & 94.23 & 94.62 & 89.63 & 102.73 \\
\hline $\mathrm{G}_{3} \times \mathrm{GS}_{1}$ & 5360.65 & $5346.90 \mathrm{ab}$ & 92.98 & 89.06 & 94.80 & 108.63 \\
\hline $\mathrm{G}_{3} \times \mathrm{GS}_{2}$ & 5747.18 & $5550.37 \mathrm{a}$ & 91.69 & 88.83 & 101.10 & 111.60 \\
\hline $\mathrm{G}_{3} \times \mathrm{GS}_{3}$ & 5823.83 & $5643.70 \mathrm{a}$ & 90.73 & 82.97 & 110.03 & 115.30 \\
\hline Grand mean & 5246.63 & 5144.44 & 91.29 & 89.80 & 99.14 & 106.99 \\
\hline LSD (0.05) (doses) & 294.00 & 286.90 & 3.06 & 2.14 & 7.63 & $\mathrm{~ns}$ \\
\hline LSD (0.05) (GS) & 256.80 & 230.70 & $\mathrm{~ns}$ & $\mathrm{~ns}$ & $\mathrm{~ns}$ & 2.01 \\
\hline DxGS interaction & ns & ns & ns & ns & ns & ns \\
\hline \% C.V. & 4.94 & 4.53 & 3.39 & 2.41 & 7.77 & 7.34 \\
\hline
\end{tabular}

*Means in each column followed by the same letter are not significantly different $(\mathrm{p}<0.05)$

$\mathrm{PHS}^{1}$ : pin head square, $\mathrm{FF}^{1}$ : first flower, T: treatment, $\mathrm{GA}_{1,2,3}$ : gibberellic acid, GS: growing stage, C: control

\section{Earliness ratio (\%)}

Table 4 shows that the average rate of earliness ratio ranged from $85 \%$ to $94 \%$ in 2015 and 2016 with an average of $91.29 \%$ in 2015 and $89.80 \%$ in 2016 in terms of $\mathrm{GA}_{3}$ 
application doses. In terms of application doses, the highest average earliness ratio was obtained from control plot; the lowest earliness ratio was obtained from gibberellic acid dose of $1200 \mathrm{cc} \mathrm{ha}^{-1}$. In terms of application times, it can be observed from Table 4 that the earliness ratio ranged between $88 \%$ and $91 \%$ respectively. According to LSD test, different earliness groups were formed in terms of application doses and the earliness ratio was decreased with increasing application doses, but there were no significant differences in terms of application times in both years. Among plant growth regulators, $\mathrm{GA}_{3}$ and auxins are vital for development of plants (Gou et al., 2010). Gibberellins by helping the development of stem, leaves and other organs of the plant can cause extension of the nodes (Bora and Sarma, 2006). For this reason, maturation of plants is delayed and thus can delay the opening of cotton bolls. Therefore, the earliness ratio may decrease. However, this decrease had not affected the harvesting date, so the plants completed their maturation in time.

\section{Plant height (cm)}

Table 4 shows that the average plant height obtained from different application doses ranged from $89 \mathrm{~cm}$ to $111 \mathrm{~cm}$ in 2015 and 2016, the average plant height was $99.14 \mathrm{~cm}$ in 2015 and $107 \mathrm{~cm}$ in 2016. In terms of application times, the highest plant height was obtained from $1200 \mathrm{cc} \mathrm{ha}^{-1}$ and the lowest plant height was obtained from the control plot. In terms of $\mathrm{GA}_{3}$ application times, it can be observed from Table 4 that the average plant height varies between $98 \mathrm{~cm}$ and $109 \mathrm{~cm}$. According to LSD test, it was found that different plant height groups were formed according to years in terms of application doses and application times, but application time $\mathrm{x}$ application dose interaction was not significant in both experimental years (Table 4). GA 3 promotes cell proliferation in plant developmental stages due to their own metabolism regulation and promotes the development of cells by increasing turgor pressure (Davies, 2010). In this case, it is thought that it activates different enzymes and has a positive effect on plant growth and thus causes plant heightening. In addition, $\mathrm{GA}_{3}$ in flax increases plant height was indicated by Rastogi et al. (2013) and Ayala-Silva et al. (2005). Our results are compatible with the findings of Emiroğlu and Turan (1974), Özdemir (1991) and Öncü (1993), and differ from the findings of Incekara and Turan (1977). This case may be derived due to the use of different $\mathrm{GA}_{3}$ doses, application times and the cotton varieties in the experiments.

\section{Boll number (no. plant ${ }^{-1}$ )}

Table 5 shows that the average number of bolls per plant obtained from $\mathrm{GA}_{3}$ application doses ranged from 10.00 no. plant ${ }^{-1}$ to 16.24 no. plant $^{-1}$ with the average of 12.76 no. plant ${ }^{-1}$ in 2015 and 13.47 no. plant $^{-1}$ in 2016 . In terms of application times, the lowest number of bolls was obtained from PHS and the highest number of bolls was obtained from PHS $+\mathrm{FF}+14$ days application. In the application time $\times \mathrm{GA}_{3}$ dose interaction, while the lowest number of bolls was obtained from the control plot and the highest number of bolls was obtained from $1200 \mathrm{cc} \mathrm{ha}^{-1}$ and PHS + FF + 14 days application. According to LSD test, it can be observed that there are different groups of number of bolls in terms of application doses and the number of bolls increased with increasing application dose in both years. Cotton yield is the result of the interaction of genetic and environmental conditions and different yield components can affect the cotton yield (Worley et al., 1974). The main feature that contributes to the cotton yield 
is the number of bolls formed per unit area or per plant (Wilson et al., 1994). GA 3 positively affects the flowering and boll formation (Mathur and Mittal, 1964; Taiz and Zeiger, 2003). Therefore, it was found that the number of bolls per plant increased and had a positive effect on the seed cotton yield.

\section{Number of sympodia (no. plant ${ }^{-1}$ )}

Table 5 shows that the average number of sympodia branches changed between 11.76 no. plant ${ }^{-1}$ and 17.82 no. plant $^{-1}$ obtained from $\mathrm{GA}_{3}$ application doses with the average of 13.40 no. plant ${ }^{-1}$ in 2015 and 16.81 no. plant ${ }^{-1}$ in 2016 . The highest numbers of sympodia branches were obtained from $1200 \mathrm{cc} \mathrm{ha}^{-1}$ and the lowest number of sympodia branches were obtained from control plot. In terms of application times, the number of sympodia branches per plant was increased by dividing the doses into three times and the highest number of sympodia branches was obtained from PHS + FF + application after two weeks. According to LSD test, it was determined that different sympodia branch number groups were formed in terms of application doses and application times in 2015, application time $\times \mathrm{GA}_{3}$ dose interaction was significant, but only application doses were statistically significant in 2016 (Table 5). 80-85\% of the bolls formed on the sympodia branches of plant. Increase in the number of sympodia branches increasing the number of bolls per plant, which contributes positively to the increase of seed cotton yield per unit area. Similar findings were determined by Çopur et al. (2010). In addition, $\mathrm{GA}_{3}$ applications increase the number of branches in flax plant (Rastogi et al., 2013). For this purpose, $1200 \mathrm{cc} \mathrm{ha}^{-1} \mathrm{GA}_{3}$ dose and PHS + FF + after two weeks applications yielded the highest number of sympodia.

\section{Seed cotton boll weight ( $\mathrm{g}$ boll $\left.^{-1}\right)$}

The most important factor affecting yield is a high-yielding cotton variety, favorable environmental conditions as well as boll weight (Mauney et al., 1978). Table 5 shows that the seed cotton boll weight increased with increasing of $\mathrm{GA}_{3}$ doses in both years. While the seed cotton weight per boll was 3.8-3.9 g in control plots, increased to 4.2$4.3 \mathrm{~g}$ at a dose of $1200 \mathrm{cc} \mathrm{ha}^{-1}$ of $\mathrm{GA}_{3}$. It was also found that seed cotton weight per boll increased by dividing application doses in terms of application times. According to the LSD test, it was determined that different seed cotton boll weight groups were formed in terms of application doses and application times were statistically significant in 2015 and 2016. Also, application time $\times \mathrm{GA}_{3}$ dose interaction was statistically significant in 2015 but not significant in 2016. GA 3 applications increased the seed cotton boll weight by increasing the number of leaves per unit area to promote more photosynthesis and contributed to increase dry matter per unit area. Similar findings were found by Abro et al. (2004). In addition, Çopur et al. (2010) in his study with different plant growth regulators; $\mathrm{GA}_{3}$ applications contribute to the formation of heavier bolls than other plant growth regulators. McCarty et al. (1987) reported that the application of $\mathrm{GA}_{3}$ reduces the seed cotton boll weight. This case may be derived due to the use of cotton varieties and the effect of different climate condition on plant growth in the experiments.

\section{Seed index (g)}

Table 6 shows that the average seed index was changed between 8.49-9.01 $\mathrm{g}$ with the average of $8.80 \mathrm{~g}$ in terms of $\mathrm{GA}_{3}$ application doses in 2015; ranged from 8.65 to $9.20 \mathrm{~g}$ with the average of $8.92 \mathrm{~g}$ in 2016 . In terms of application doses, the highest seed index 
was obtained from $1200 \mathrm{cc} \mathrm{ha}^{-1}$ and the lowest seed index was obtained from the control plot. In terms of application times, the average seed index changes between 8.68 and $8.92 \mathrm{~g}$ in 2015 and 8.67 and $9.27 \mathrm{~g}$ in 2016. When the GA doses and control parcels were compared in terms of application doses according to LSD test, the results obtained from $\mathrm{GA}_{1}, \mathrm{GA}_{2}$ and $\mathrm{GA}_{3}$ applications were similar but higher than the control parcel in 2015. In 2016, GA 2 and $\mathrm{GA}_{3}$ doses were similar but higher than $\mathrm{GA}_{1}$ and control parcels. It can be seen that seed index was increases with increasing of $\mathrm{GA}_{2}$ and $\mathrm{GA}_{3}$ doses. $\mathrm{GA}_{2}$ and $\mathrm{GA}_{3}$ applications accelerated the plant growth along with cell division and contributed to the increase of dry matter per unit area and accordingly increased seed weight. Erdemli and Kaya (2015) in the sunflower and Mustaq et al. (2018) in onion reported that an increase in $\mathrm{GA}_{3}$ doses cause an increase in seed weight. According to these results, it can be said that GA applications had positive effect on seed size.

Table 5. Boll number, number of sympodia, seed cotton boll weight and its contributions in response to gibberellic acid and growing stages in 2015 and 2016

\begin{tabular}{|c|c|c|c|c|c|c|}
\hline \multirow[t]{2}{*}{ GA application doses } & \multicolumn{2}{|c|}{$\begin{array}{l}\text { Boll number } \\
\left(\text { no. plant }{ }^{-1}\right)\end{array}$} & \multicolumn{2}{|c|}{$\begin{array}{c}\text { Number of sympodia } \\
\left(\text { no. } \text { plant }^{-1}\right)\end{array}$} & \multicolumn{2}{|c|}{$\begin{array}{l}\text { Seed cotton boll } \\
\text { weight }\left(\mathrm{g} \mathrm{boll}^{-1}\right)\end{array}$} \\
\hline & 2015 & 2016 & 2015 & 2016 & 2015 & 2016 \\
\hline Control (C) & $10.00 \mathrm{c}$ & $11.10 \mathrm{c}$ & $11.76 \mathrm{~d}$ & $15.23 \mathrm{c}$ & $3.95 \mathrm{c}$ & $3.81 \mathrm{c}$ \\
\hline $\mathrm{GA}_{1}\left(400 \mathrm{cc} \mathrm{ha} \mathrm{h}^{-1}\right)$ & $11.96 \mathrm{~b}$ & $13.44 \mathrm{~b}$ & $12.90 \mathrm{c}$ & $16.86 \mathrm{~b}$ & $4.12 \mathrm{~b}$ & $3.95 \mathrm{bc}$ \\
\hline $\mathrm{GA}_{2}\left(800 \mathrm{cc} \mathrm{ha}^{-1}\right)$ & $12.86 \mathrm{~b}$ & $14.06 \mathrm{~b}$ & $13.66 \mathrm{~b}$ & $17.32 \mathrm{ab}$ & $4.21 \mathrm{~b}$ & $4.04 \mathrm{ab}$ \\
\hline $\mathrm{GA}_{3}\left(1200 \mathrm{cc} \mathrm{ha}^{-1}\right)$ & $16.24 \mathrm{a}$ & $15.29 \mathrm{a}$ & $15.25 \mathrm{a}$ & $17.82 \mathrm{a}$ & $4.37 \mathrm{a}$ & $4.22 \mathrm{a}$ \\
\hline \multicolumn{7}{|l|}{ Growing stage (GS) } \\
\hline $\mathrm{PHS}^{1}$ & $11.32 \mathrm{c}$ & $12.35 \mathrm{~b}$ & $12.20 \mathrm{~b}$ & 16.58 & $4.06 \mathrm{~b}$ & $3.69 \mathrm{c}$ \\
\hline $\mathrm{PHS}+\mathrm{FF}^{2}$ & $12.43 \mathrm{~b}$ & $13.02 \mathrm{~b}$ & $13.56 \mathrm{a}$ & 16.82 & $4.13 \mathrm{~b}$ & $4.03 \mathrm{~b}$ \\
\hline $\mathrm{PHS}+\mathrm{FF}+$ after two weeks & $14.54 \mathrm{a}$ & $13.05 \mathrm{a}$ & $14.42 \mathrm{a}$ & 17.03 & $4.31 \mathrm{a}$ & $4.29 \mathrm{a}$ \\
\hline \multicolumn{7}{|l|}{ Interaction } \\
\hline $\mathrm{CxGS}_{1}$ & $10.00 \mathrm{~d}$ & 11.10 & $11.76 \mathrm{~d}$ & 15.23 & 3.95 & $3.81 \mathrm{~cd}$ \\
\hline $\mathrm{CxGS}_{2}$ & $10.17 \mathrm{~cd}$ & 12.43 & $11.70 \mathrm{~d}$ & 16.70 & 3.92 & $3.52 \mathrm{~d}$ \\
\hline $\mathrm{CxGS}_{3}$ & $10.70 \mathrm{~cd}$ & 12.23 & $12.13 \mathrm{~d}$ & 16.70 & 4.05 & $3.63 \mathrm{~d}$ \\
\hline $\mathrm{G}_{1} \times \mathrm{GS}_{1}$ & $14.40 \mathrm{~b}$ & 13.63 & $13.20 \mathrm{c}$ & 17.70 & 4.29 & $3.82 \mathrm{~cd}$ \\
\hline $\mathrm{G}_{1} \times \mathrm{GS}_{2}$ & $10.00 \mathrm{~d}$ & 11.10 & $11.76 \mathrm{~d}$ & 15.23 & 3.95 & $3.81 \mathrm{~cd}$ \\
\hline $\mathrm{G}_{1} \times \mathrm{GS}_{3}$ & $11.60 \mathrm{~cd}$ & 12.27 & $13.50 \mathrm{c}$ & 16.90 & 4.07 & $4.09 \mathrm{bc}$ \\
\hline $\mathrm{G}_{2} \times \mathrm{GS}_{1}$ & $12.03 \mathrm{c}$ & 13.67 & $13.70 \mathrm{c}$ & 17.50 & 4.15 & $4.09 \mathrm{bc}$ \\
\hline $\mathrm{G}_{2} \times \mathrm{GS}_{2}$ & $16.10 \mathrm{~b}$ & 15.03 & $15.30 \mathrm{~b}$ & 17.63 & 4.34 & $4.14 \mathrm{bc}$ \\
\hline $\mathrm{G}_{2} \times \mathrm{GS}_{3}$ & $10.00 \mathrm{~d}$ & 11.10 & $11.76 \mathrm{~d}$ & 15.23 & 3.95 & $3.81 \mathrm{~cd}$ \\
\hline $\mathrm{G}_{3} \times \mathrm{GS}_{1}$ & $14.10 \mathrm{~b}$ & 15.63 & $13.50 \mathrm{c}$ & 16.97 & 4.37 & $4.25 \mathrm{~b}$ \\
\hline $\mathrm{G}_{3} \times \mathrm{GS}_{2}$ & $15.83 \mathrm{~b}$ & 16.27 & $15.17 \mathrm{~b}$ & 17.77 & 4.43 & $4.42 \mathrm{ab}$ \\
\hline $\mathrm{G}_{3} \times \mathrm{GS}_{3}$ & $18.23 \mathrm{a}$ & 17.20 & $17.26 \mathrm{a}$ & 18.13 & 4.80 & $4.70 \mathrm{a}$ \\
\hline Grand mean & 12.76 & 13.47 & 13.40 & 16.81 & 4.17 & 4.01 \\
\hline $\operatorname{LSD}(0.05)($ doses $)$ & 1.56 & 1.15 & 0.98 & ns & 0.15 & 0.20 \\
\hline LSD (0.05) (GS) & 0.78 & 0.82 & 0.59 & 0.57 & 0.11 & 0.24 \\
\hline DxGS interaction & 2.00 & ns & 1.02 & ns & ns & 0.34 \\
\hline$\%$ C.V. & 9.15 & 8.59 & 4.42 & 3.45 & 3.60 & 4.95 \\
\hline
\end{tabular}

*Means in each column followed by the same letter are not significantly different $(\mathrm{p}<0.05)$

$\mathrm{PHS}^{1}$ : pin head square, $\mathrm{FF}^{1}$ : first flower, $\mathrm{T}$ : treatment, $\mathrm{GA}_{1,2,3}$ : gibberellic acid, GS: growing stage 
Table 6. Seed index, ginning outturn, fiber length and its contributions in response to gibberellic acid and growing stages in 2015 and 2016

\begin{tabular}{|c|c|c|c|c|c|c|}
\hline \multirow{2}{*}{ GA application doses } & \multicolumn{2}{|c|}{ Seed index $(g)$} & \multicolumn{2}{|c|}{ Ginning outturn (g) } & \multicolumn{2}{|c|}{ Fiber length $(\mathrm{mm})$} \\
\hline & 2015 & 2016 & 2015 & 2016 & 2015 & 2016 \\
\hline Control (C) & $8.49 \mathrm{~b}$ & $8.65 \mathrm{~b}$ & $41.02 \mathrm{~b}$ & $41.49 \mathrm{~b}$ & $28.49 \mathrm{~b}$ & 27.62 \\
\hline $\mathrm{GA}_{1}\left(400 \mathrm{cc} \mathrm{ha}^{-1}\right)$ & $8.75 \mathrm{ab}$ & $8.74 b$ & $41.94 \mathrm{a}$ & $42.95 \mathrm{a}$ & $29.58 \mathrm{a}$ & 27.39 \\
\hline $\mathrm{GA}_{2}\left(800 \mathrm{cc} \mathrm{ha}^{-1}\right)$ & $8.93 \mathrm{a}$ & $9.08 \mathrm{a}$ & $41.76 \mathrm{ab}$ & $43.01 \mathrm{a}$ & $29.83 \mathrm{a}$ & 28.16 \\
\hline $\mathrm{GA}_{3}\left(1200 \mathrm{cc} \mathrm{ha}^{-1}\right)$ & $9.01 \mathrm{a}$ & $9.20 \mathrm{a}$ & $42.36 \mathrm{a}$ & $43.35 \mathrm{a}$ & $29.91 \mathrm{a}$ & 28.51 \\
\hline \multicolumn{7}{|l|}{ Growing stage (GS) } \\
\hline $\mathrm{PHS}^{1}$ & 8.68 & $8.67 \mathrm{~b}$ & 41.62 & 42.70 & $28.82 \mathrm{~b}$ & 27.50 \\
\hline $\mathrm{PHS}+\mathrm{FF}^{2}$ & 8.78 & $8.81 \mathrm{~b}$ & 41.77 & 42.75 & $29.54 \mathrm{a}$ & 27.86 \\
\hline PHS + FF + after two weeks & 8.92 & $9.27 \mathrm{a}$ & 41.93 & 42.65 & $30.00 \mathrm{a}$ & 28.40 \\
\hline \multicolumn{7}{|l|}{ Interaction } \\
\hline $\mathrm{CxGS}_{1}$ & 8.49 & $8.65 \mathrm{~b}$ & 41.03 & 41.49 & 28.49 & 27.62 \\
\hline $\mathrm{CxGS}_{2}$ & 8.52 & $8.68 \mathrm{~b}$ & 41.54 & 42.79 & 28.74 & 27.37 \\
\hline $\mathrm{CxGS}_{3}$ & 8.83 & $8.62 \mathrm{~b}$ & 41.69 & 42.98 & 29.12 & 27.76 \\
\hline $\mathrm{G}_{1} \times \mathrm{XS}_{1}$ & 8.89 & $8.72 \mathrm{~b}$ & 42.20 & 43.53 & 28.91 & 27.26 \\
\hline $\mathrm{G}_{1} \times \mathrm{XS}_{2}$ & 8.50 & $8.65 \mathrm{~b}$ & 41.02 & 41.49 & 28.49 & 27.62 \\
\hline $\mathrm{G}_{1} \times \mathrm{XS}_{3}$ & 8.79 & $8.69 \mathrm{~b}$ & 42.10 & 42.97 & 29.66 & 27.17 \\
\hline $\mathrm{G}_{2} \times \mathrm{XS}_{1}$ & 8.88 & $8.89 \mathrm{~b}$ & 41.52 & 43.39 & 29.76 & 27.98 \\
\hline $\mathrm{G}_{2} \times \mathrm{XS}_{2}$ & 8.97 & $9.03 \mathrm{~b}$ & 42.42 & 43.14 & 30.26 & 28.65 \\
\hline $\mathrm{G}_{2} \times \mathrm{XS}_{3}$ & 8.50 & $8.65 \mathrm{~b}$ & 41.02 & 41.49 & 28.49 & 27.62 \\
\hline $\mathrm{G}_{3} \times \mathrm{XS}_{1}$ & 8.94 & $8.85 \mathrm{~b}$ & 42.16 & 43.07 & 30.33 & 27.63 \\
\hline $\mathrm{G}_{3} \times \mathrm{XS}_{2}$ & 9.10 & $9.73 \mathrm{a}$ & 42.07 & 42.65 & 30.61 & 28.74 \\
\hline $\mathrm{G}_{3} \mathrm{xGS}_{3}$ & 9.17 & $9.85 \mathrm{a}$ & 42.46 & 43.39 & 30.56 & 29.60 \\
\hline Grand mean & 8.80 & 8.92 & 41.77 & 42.70 & 29.45 & 27.92 \\
\hline LSD $(0.05)$ (doses) & 0.31 & 0.28 & 0.80 & 0.75 & 0.78 & $\mathrm{~ns}$ \\
\hline LSD (0.05) (GS) & $\mathrm{ns}$ & 0.28 & $\mathrm{~ns}$ & $\mathrm{~ns}$ & 0.50 & $\mathrm{~ns}$ \\
\hline D x GS interaction & $\mathrm{ns}$ & 0.48 & $\mathrm{~ns}$ & $\mathrm{~ns}$ & $\mathrm{~ns}$ & ns \\
\hline$\%$ C.V. & 3.52 & 3.16 & 1.92 & 1.77 & 2.67 & 3.13 \\
\hline
\end{tabular}

*Means in each column followed by the same letter are not significantly different $(\mathrm{p}<0.05)$

$\mathrm{PHS}^{1}$ : pin head square, $\mathrm{FF}^{1}$ : first flower, $\mathrm{T}$ : treatment, $\mathrm{GA}_{1,2,3}$ : gibberellic acid, GS: growing stage, $\mathrm{C}$ : control

\section{Ginning outturn (g)}

Marketing of cotton in Turkey is done more in ginning enterprises as seed cotton. Ginning enterprises in cotton purchase are taking into account the more ginning outturn as well as the color and the amount of foreign matter for price. For this purpose, ginning outturn is important in the marketing of cotton seed. Table 6 shows that the average ginning outturn was obtained from the application doses of $\mathrm{GA}_{3}$ changed between 41$42.36 \%$ in 2015 with the average of $41.77 \%$, and between $41-43 \%$ with the average of $42.70 \%$ in 2016 . While the highest ginning outturn was obtained from $1200 \mathrm{cc} \mathrm{ha}^{-1}$, the lowest ginning outturns from the control plot. According to LSD test, it was found that different ginning outturn groups were formed in terms of application doses but there were no significant differences in terms of application times and $\mathrm{GA}_{3}$ dose $\mathrm{x}$ application 
time's interaction in both years. In the findings obtained in GA application doses, $\mathrm{GA}_{1}$, $\mathrm{GA}_{2}$ and $\mathrm{GA}_{3}$ applications were similar in both years but higher results were obtained compared to the control parcels. In the studies of Emiroğlu and Turan (1974) and Özdemir (1991) with different plant growth regulators reported that the gibberellic acid had not affected ginning outturn. This situation differs from our findings. Different results may be observed due to the different climatic conditions of the studies, application time and $\mathrm{GA}_{3}$ dose and different cotton varieties used in the experiments.

\section{Fiber length ( $\mathrm{mm})$}

Table 6 shows that the average fiber length obtained from different $\mathrm{GA}_{3}$ application doses varied between 28.49 and $29.91 \mathrm{~mm}$ in 2015 with the average of $29.45 \mathrm{~mm}$ were varied between 27 and $28 \mathrm{~mm}$ with the average of $27.92 \mathrm{~mm}$ in 2016 . While the longest fibers were obtained from $1200 \mathrm{cc} \mathrm{ha}^{-1}$ the shortest fibers were obtained from the control plot. In terms of application times, the average fiber length varies between 28.82 and $30.00 \mathrm{~mm}$ in 2015 and between 27.50 and $28.40 \mathrm{~mm}$ in 2016. In 2016, it can be seen that, $\mathrm{GA}_{1}, \mathrm{GA}_{2}$ and $\mathrm{GA}_{3}$ applications were similar but they produce higher results than the control parcel. According to LSD test; fiber lengths were affected by $\mathrm{GA}_{3}$ applications in 2015 but were not affected in 2016. Although fiber length is an inherited character, it can be affected by environmental conditions and cultivation techniques. In the study of Gokani and Thaker (2002); fiber lengths in both in vitro and in vivo were positively affected from $\mathrm{GA}_{3}$ applications in three cotton varieties used in the experiment; Oral (1986), Jost and Dolar (2004) and Çopur et al. (2010) reported that $\mathrm{GA}_{3}$ had no significant effect on fiber length. This may be observed due to the fact that the trials were conducted with different $\mathrm{GA}_{3}$ doses and cotton varieties under different environmental conditions.

\section{Fiber fineness (micronaire)}

Table 7 shows that the average fiber fineness value ranged from 4.18 to 4.55 micronaire (mic) with an average of 4.34 mic in terms of $\mathrm{GA}_{3}$ application doses in 2015 , ranged from 4.77 to 4.91 mic with an average of 4.86 mic in 2016. In terms of application times, the average fiber fineness varies between 4.30 and 4.42 mic with the average of $4.34 \mathrm{mic}$ in 2015 , varies between 4.83 and 4.96 mic with an average of $4.86 \mathrm{mic}$ in 2016 . In terms of $\mathrm{GA}_{3}$ doses, it can be observed that the coarser fibers were obtained from $800 \mathrm{cc} \mathrm{ha}^{-1}$ and the finest fibers were obtained from the control plot in 2015 but there were no significant differences in terms of application times and $\mathrm{GA}_{3}$ doses in 2016. It can be seen from Table 7 that the fiber fineness partially decreased with increasing $\mathrm{GA}_{3}$ doses.

Although the fiber fineness value is an inherited property, it can be affected by environmental conditions. In particular, temperature and consequently photosynthesis and carbohydrate deposition may affect fiber fineness. Thus, with the dose increases, the maturation of the plants is delayed, and the fibers become coarse due to the increase of dry matter in the plants. Although the fiber fineness is partially getting coarser with increasing of $\mathrm{GA}_{3}$ dose, the values obtained do not pose a problem in terms of its use in textile (expected values are 3.8-4.6 mic). Our results are partially contradicting with the findings of Özdemir (1991), Zibdieh et al. (1998) and Çopur et al. (2010) and this may be observed due to the differences of $\mathrm{GA}_{3}$ doses and the cotton varieties used in the trials. 
Table 7. Fiber fineness, fiber strength, fiber uniformity and its contributions in response to gibberellic acid and growing stages in 2015 and 2016

\begin{tabular}{|c|c|c|c|c|c|c|}
\hline \multirow{2}{*}{ GA application doses } & \multicolumn{2}{|c|}{ Fiber fineness (mic) } & \multicolumn{2}{|c|}{ Fiber strength $\left(\mathrm{g} \mathrm{tex}^{-1}\right)$} & \multicolumn{2}{|c|}{ Fiber uniformity $(\%)$} \\
\hline & 2015 & 2016 & 2015 & 2016 & 2015 & 2016 \\
\hline Control (C) & $4.18 \mathrm{~b}$ & 4.77 & 30.70 & 29.23 & $83.23 \mathrm{c}$ & $82.97 \mathrm{c}$ \\
\hline $\mathrm{GA}_{1}\left(400 \mathrm{cc} \mathrm{ha}^{-1}\right)$ & $4.32 \mathrm{ab}$ & 4.82 & 31.66 & 28.32 & $84.58 \mathrm{~b}$ & $82.86 \mathrm{c}$ \\
\hline $\mathrm{GA}_{2}\left(800 \mathrm{cc} \mathrm{ha}^{-1}\right)$ & $4.55 \mathrm{a}$ & 4.93 & 31.97 & 29.17 & $84.98 \mathrm{a}$ & $84.16 \mathrm{~b}$ \\
\hline $\mathrm{GA}_{3}\left(1200 \mathrm{cc} \mathrm{ha}^{-1}\right)$ & $4.33 \mathrm{ab}$ & 4.91 & 32.37 & 29.13 & $85.24 \mathrm{a}$ & $85.27 \mathrm{a}$ \\
\hline \multicolumn{7}{|l|}{ Growing stage (GS) } \\
\hline $\mathrm{PHS}^{1}$ & 4.42 & 4.83 & 31.28 & 28.78 & $84.27 \mathrm{~b}$ & 84.02 \\
\hline $\mathrm{PHS}+\mathrm{FF}^{2}$ & 4.31 & 4.78 & 31.48 & 29.26 & $84.55 \mathrm{ab}$ & 83.72 \\
\hline PHS + FF + after two weeks & 4.30 & 4.96 & 32.26 & 28.86 & $84.71 \mathrm{a}$ & 83.70 \\
\hline \multicolumn{7}{|l|}{ Interaction } \\
\hline $\mathrm{CxGS}_{1}$ & 4.18 & 4.77 & 30.70 & 29.23 & $83.23 \mathrm{~d}$ & 82.97 \\
\hline $\mathrm{CxGS}_{2}$ & 4.37 & 4.79 & 31.06 & 27.30 & $84.63 \mathrm{bc}$ & 83.33 \\
\hline $\mathrm{CxGS}_{3}$ & 4.58 & 4.78 & 31.60 & 29.50 & $84.80 \mathrm{bc}$ & 84.87 \\
\hline $\mathrm{G}_{1} \mathrm{XGS} \mathrm{S}_{1}$ & 4.56 & 4.74 & 31.73 & 29.07 & $84.43 \mathrm{c}$ & 84.90 \\
\hline $\mathrm{G}_{1} \mathrm{XGS} \mathrm{S}_{2}$ & 4.18 & 4.77 & 30.70 & 29.23 & $83.23 \mathrm{~d}$ & 82.97 \\
\hline $\mathrm{G}_{1} \times \mathrm{XS}_{3}$ & 4.45 & 4.73 & 31.37 & 29.20 & $84.33 \mathrm{c}$ & 82.67 \\
\hline $\mathrm{G}_{2} \mathrm{XGS}_{1}$ & 4.38 & 5.07 & 31.73 & 29.73 & $84.90 \mathrm{bc}$ & 83.67 \\
\hline $\mathrm{G}_{2} \times \mathrm{XS}_{2}$ & 4.24 & 4.97 & 32.13 & 28.87 & $85.73 \mathrm{a}$ & 85.57 \\
\hline $\mathrm{G}_{2} \mathrm{XGS}_{3}$ & 4.18 & 4.77 & 30.70 & 29.23 & $83.23 \mathrm{~d}$ & 82.97 \\
\hline $\mathrm{G}_{3} \times \mathrm{XS}_{1}$ & 4.14 & 4.94 & 32.53 & 28.47 & $84.77 \mathrm{bc}$ & 82.57 \\
\hline $\mathrm{G}_{3} \times \mathrm{XS}_{2}$ & 4.69 & 4.95 & 32.57 & 28.27 & $85.27 \mathrm{ab}$ & 83.93 \\
\hline $\mathrm{G}_{3} \times \mathrm{GS}_{3}$ & 4.18 & 5.04 & 33.23 & 29.47 & $85.57 \mathrm{a}$ & 85.33 \\
\hline Grand mean & 4.34 & 4.86 & 31.67 & 28.96 & 84.51 & 83.81 \\
\hline LSD (0.05) (Doses) & 0.25 & $\mathrm{~ns}$ & $\mathrm{~ns}$ & ns & 0.39 & 1.04 \\
\hline LSD (0.05) (GS) & $\mathrm{ns}$ & $\mathrm{ns}$ & $\mathrm{ns}$ & $\mathrm{ns}$ & 0.32 & $\mathrm{~ns}$ \\
\hline D x GS interaction & $\mathrm{ns}$ & $\mathrm{ns}$ & $\mathrm{ns}$ & $\mathrm{ns}$ & 0.67 & $\mathrm{~ns}$ \\
\hline$\%$ C.V. & 5.67 & 5.07 & 5.75 & 6.27 & 0.46 & 1.25 \\
\hline
\end{tabular}

*Means in each column followed by the same letter are not significantly different $(\mathrm{p}<0.05)$

$\mathrm{PHS}^{1}$ : pin head square, $\mathrm{FF}^{1}$ : first flower, $\mathrm{T}$ : treatment, $\mathrm{GA}_{1,2,3}$ : gibberellic acid, GS: growing stage, $\mathrm{C}$ : control

\section{Fiber strength ( tex $\left.^{-1}\right)$}

Table 7 shows that the average fiber strength obtained was $31.67 \mathrm{~g} \mathrm{tex}^{-1}$ according to $\mathrm{GA}_{3}$ application doses in 2015 and $28.96 \mathrm{~g} \mathrm{tex}^{-1}$ in 2016, the highest fiber strength was obtained from $1200 \mathrm{cc} \mathrm{ha}^{-1}$ and the lowest fiber strength was obtained from the control plot. According to LSD test; different fiber breakage strength groups has not formed in terms of $\mathrm{GA}_{3}$ doses, application times and interaction of application doses $\mathrm{x}$ application times, but fiber breakage strength increased partially with increasing of $\mathrm{GA}_{3}$ doses, but it was not statistically significant. This shows that $\mathrm{GA}_{3}$ applications have no significant effect on the fiber breakage strength. Similar findings were determined by Özdemir (1991), Zibdieh et al. (1998) and Çopur et al. (2010). 


\section{Fiber uniformity (\%)}

Table 7 shows that the average fiber uniformity ratio obtained from gibberellic acid application doses varies between $83.23 \%$ and $85.24 \%$ with the average of $84.51 \%$ in 2015 , and it was varied between $82.97 \%$ and $85.27 \%$ with the average of $83.81 \%$ in 2016. While the highest fiber uniformity was obtained from $1200 \mathrm{cc} \mathrm{ha}^{-1}$ and the lowest fiber uniformity was obtained from the control plot. In terms of $\mathrm{GA}_{3}$ application times, the average fiber uniformity was varied between 84.27 and $84.71 \%$ in 2015 and varies between 83.70 and $84.02 \%$ in 2016 . As a result of the analysis of variance: There were significant differences in all sources of variation in terms of fiber uniformity for 2015 , but only a significant difference was found in terms of application times in 2016 (Table 7). Fiber uniformity ratio is calculated in the fiber development diagram as $50 \%$ fiber length in fiber distribution by comparing to the $2.5 \%$ of fiber length. Thus, fiber length is positively affected with increasing doses of $\mathrm{GA}_{3}$, so that a homogeneous length is obtained with the development of fibers. Increased fiber uniformity is desirable and $\mathrm{GA}_{3}$ doses have a positive effect on fiber uniformity ratio. Therefore, in $\mathrm{GA}_{3}$ applications, the dose of $1200 \mathrm{cc} \mathrm{ha}^{-1}$ was divided into three as PHS + FF + after two weeks or divided into two as PHS + FF.

\section{Conclusion}

In cotton farming, the most important issue that the producers have focused on seed cotton yield. In this study the seed cotton yield varied between $4882.77 \mathrm{~kg} \mathrm{ha}^{-1}$ and $5557.15 \mathrm{~kg} \mathrm{ha}^{-1}$. Cotton yield is the result of interaction of genetic and environmental conditions, and different yield components can affect the seed cotton yield. Therefore, in order to minimize the negative effects of environmental conditions on plants, to maintain normal physiological events in plants and to reach maximum yield potential, it is important to give some phyto hormones to the plant externally. One of the plant growth regulators commonly used in agricultural production is gibberellic acid. Gibberellins promote their growth as they increase the turgor pressure of the cells by promoting cell proliferation during plant developmental stages, thus regulating their own metabolism. Furthermore, GA positively affects flowering, boll formation and number of bolls per plant, thus contributing positively to seed cotton yield. According to our study with different GA doses the most appropriate dose of GA under semi-arid climatic conditions is $1200 \mathrm{cc} \mathrm{ha}^{-1}$ and it should be preferred to divide into three doses as beginning of squaring + beginning of flowering + 14 days after beginning of flowering. In addition, it would be useful to carry out more studies related to plant growth regulators at different locations in order to determine the variable dose combinations of GA and the response of different cotton varieties.

\section{REFERENCES}

[1] Abro, G. H., Syed, T. S., Zhang, M. S. (2004): Effect of application of a plant growth regulator and micronutrients on insect pest infestation and yield components of cotton. Journal of Entomology 1(1): 12-16.

[2] Anonymous (1989): MSTAT Development Team. MSTAT User's Guide, A Microcomputer Program for the Design Management and Analysis of Agronomic Research Experiments. - Michigan State University, USA. 
[3] Anonymous (1997): High Volume Instruments (HVI) Catalog. - Costumer Information Service No: 40, May, Sweden.

[4] Anonymous (2006): GAP Agricultural Research Institute. - Soil Analysis Laboratory Results, Sanliurfa, Turkey.

[5] Anonymous (2017): Official record of Meteorology Directory. - Şanliurfa, Turkey.

[6] Anonymous (2019a): Record of the International Cotton Advisory Committee (ICAC) Report, April Monthly Report. - ICAC, Washington, DC.

[7] Anonymous (2019b): Official Record of Turkish Statistical Institute. http://www.tuik.gov.tr/bitkiselapp/bitkisel.zul (accessed on 20 April 2019).

[8] Ayala-Silva, T., Akin, D. E., Foulk, J., Dodd, R. B. (2005): Effect of growth regulators on yield and fiber quality and quantity in flax (Linum usitatissimum L.). - Plant Growth Regulation Society of America 33: 90-100.

[9] Bora, R. K., Sarma, C. M. (2006): Effect of gibberellic acid and cycocel on growth, yield and protein content of pea. - Asian Journal of Plant Sciences 5: 324-330.

[10] Çopur, O., Demirel, U., Karakus, M. (2010): Effects of several plant growth regulators on the yield and fiber quality of cotton (Gossypium hirsutum L.). - Notulae Botanicae Horti Agrobotanici Cluj-Napoca 38(3): 104-110.

[11] Davies, P. J. (1995): Plant Hormones and Their Role in Plant Growth Development. 2nd Ed. - Kluwer, Dordrecht.

[12] Davies, P. J. (2010): The Plant Hormones: Their Nature, Occurrence, and Functions. - In: Davies, P. J. (ed.) Plant Hormones. Springer, Netherlands, pp. 1-15.

[13] Eid, E. T., Aggory, E. A. (1986): Effect of $\mathrm{GA}_{3}$ different applications on yield, components and mineral status of cotton plant, variety Giza-75 (G. barbadense L.). Field Crops Abs 39(11): 8829.

[14] Emiroğlu, Ş. H., Turan, Z. M. (1974): A research on the effects of cycocel and gibberellin on the anatomical and technological properties of cotton. - Plant 1(13): 415-425 (in Turkish).

[15] Emongor, V. (2007): Gibberellic acid (GA3) influence on vegetative growth, nodulation and yield of cowpea (Vigna unguiculata L.) Walp. - Journal of Agronomy 6: 509-517.

[16] Erdemli, H., Kaya, M. D. (2015): The effects of gibberellic acid doses on yield and germination under abiotic stress conditions in sunflower (Helianthus annuus L.). Journal of Field Crops Central Research Institute 24(1): 38-46 (in Turkish).

[17] Gokani, S. J., Thaker, V. S. (2002): Role of gibberellic acid in cotton fibre development. - Journal of Agricultural Science 138: 255-260.

[18] Gou, J., Strauss, S. H., Tsai, C. J., Fang, K., Chen, Y., Jiang, X., Busov, V. B. (2010): Gibberellins regulate lateral root formation in Populus through interactions with Auxin and other hormones. - The Plant Cell 22(2): 623-639.

[19] Güllüoğlu, L. (2004): Determination of usage of plant growth regulators in soybean (Glycine max L.) farming under Harran plain conditions. University of Harran (Turkey). Journal of the Faculty of Agriculture (in Turkish) 8(3-4): 17-23.

[20] İncekara, F., Turan, Z. M. (1977): The effect of various gibberellin doses on some agronomic and technological characters in cotton (G. hirsutum L.). - Plant 4(2): 161-168 (in Turkish).

[21] Jost, P., Dolar, M. (2004): Comparison of mepiquat pentaborate and mepiquat chloride effects on DP555BR. - Proc. Beltwide Cotton Conf., San Antonio. Natl. Cotton Counc. Am., Memphis, TN, 5-9 January, pp. 2204-2206.

[22] Kurt, O., Leitch, M. H., Avc1oğlu, R. (1994): An investigation into the effects of the application of plant growth regulators (chlor mepiquat and ethaphon) on growth, development and yield of linseed (Linum usitatissimum L.). - The First National Field Crops Congress of Turkey. Proceedings of Plant Breeding, University of Ege, Faculty of Agriculture, Department of Field Crops. Izmir, Turkey 2: 219-222 (in Turkish).

[23] Mathur, S. N., Mittal, S. P. (1964): Effect of gibberellin on flowering in cotton. Physiologia Plantarum 17: 275-278. 
[24] Mauney, J. R., Fry. K. E., Guinn, G. (1978): Relationship of photosynthetic rate to growth and fruiting of cotton, soybean, sorghum and sunflower. - Crop Science 18: 259263.

[25] McCarty, J. C., Jenkins, J. N., Hedin, P. A., Shepherd, R. L., Parrott, W. L. (1987): The effects of plant growth regulators on cotton yield in two environments. - Miss. Agric. For. Exp. Sta. Res. Rep. 12: 1-4.

[26] McCarty, J. C., Hedin, P. A., Hayes, R. W. (2009): Minimal effects of foliar application of gibberellic acid and carbohydrates on the yield of cotton lint. - Mississippi State University Agricultural and Forestry Experiment Station Report, USA.

[27] Mert, M., Çopur, O., Özek, H. Z. (2015): Changes in the production of fiber crops and new searches. - Turkish Chamber of Agricultural Engineers, 8th Technical Congress, 1216 January 2015. Ankara, Turkey, pp. 450-482 (in Turkish).

[28] Mustaq, S., Amjad, M., Ziaf, K., Afzal, I. (2018): Gibberellins application timing modulates growth, physiology, and quality characteristics of two onion (Allium cepa L.) cultivars. - Environmental Science and Pollution Research 25(25): 25155-25161.

[29] Oral, A. (1986): Effect of some plant growth regulator on shedding in cotton. Mediterranean University, Faculty of Agriculture, First Turkish Foliar Fertilizers and Plant Hormones Symposium, 23-24 October, Antalya, Turkey (in Turkish).

[30] Öncü, S. (1993): A research on the effect of some growth regulators and harvest aid application in cotton (Gossypium hirsutum L.). - Ege University, Graduate School of Natural and Applied Sciences, PhD. Thesis, İzmir, Turkey, pp.45-50 (in Turkish).

[31] Özdemir, M. (1991): The effect of some growth regulators on yield and quality in cotton (Gossypium hirsutum L.). - Ege University, Graduate School of Natural and Applied Sciences, MSc Thesis, İzmir, Turkey (in Turkish).

[32] Parveen, S., Iqbal, R. M., Akram, M., Iqbal, F., Tahir, M., Rafay, M. (2017): Improvement of growth and productivity of cotton (Gossypium hirsutum L.) through foliar applications of naphthalene acetic acid. - Semina: Ciências Agrárias, Londrina 38(2): 561-570.

[33] Rastogi, A., Siddiqui, A., Mishra, B. K., Srivastava, M., Pandey, R., Misra, P., Singh, M., Shukla, S. (2013): Effect of auxin and gibberellic acid on growth and yield components of linseed (Linum usitatissimum L.). - Crop Breeding and Applied Biotechnology 13: 136-143.

[34] Taiz, L., Zeiger, E. (2003): Plant Physiology. Third Ed. - Sinauer Associates, Sunderland, MA.

[35] Ülger, S., Atmaca, S., Demiral, S. (2018): The effects of $\mathrm{GA}_{3}$ treatment on yield, carbohydrate, and endogenous hormone changes in Memecik olive cultivar. - Turkish Journal of Agriculture and Forestry 42: 75-81.

[36] Wilson, F. D., Flint, H. M., Deaton, W. R., Buehler, R. E. (1994): Yield, yield components, and fiber properties of insect-resistant cotton lines containing a Bacillus thuringiensis toxin gene. - Crop Science 34: s 38-41.

[37] Worley S., Culp, T. W., Harrell, D. C. (1974): The relative contributions of yield components to lint yield of upland cotton, Gossypium hirsutum L. - Euphytica 23: 399403.

[38] Worley, S. J. R., Harmon, H. R., Harrel, D. C., Culp, T. W. (1976): Ontogenetic model of cotton yield. - Crop Science 16: 30-34.

[39] Zibdieh, A., Mouharram, S., Khour1, F. (1998): Effect of growth regulators, PGR IV, cytokin, cytoplex and atonik in Syria in 1996 and 1997 seasons. - FAO Interregional Cooperative Research Network on Cotton, 14-20 July, Bari, Italy, pp. 58-61. 